\title{
The Psychological Well-Being of 'Houseman' Medical Officers in Malaysia
}

Tambol Z., Bakar, A. Y. A., Mahmud, M. I., \& Karim, D. N. F. M.

To Link this Article: http://dx.doi.org/10.6007/IJARBSS/v10-i11/8167

DOI:10.6007/IJARBSS/v10-i11/8167

Received: 26 September 2020, Revised: 20 October 2020, Accepted: 14 November 2020

Published Online: 26 November 2020

In-Text Citation: (Tambol et al., 2020)

To Cite this Article: Tambol, Z., Bakar, A. Y. A., Mahmud, M. I., \& Karim, D. N. F. M. (2020). The Psychological Well-Being of 'Houseman' Medical Officers in Malaysia. International Journal of Academic Research in Business and Social Sciences, 10(11), 1006-1015.

\section{Copyright: (c) 2020 The Author(s)}

Published by Human Resource Management Academic Research Society (www.hrmars.com)

This article is published under the Creative Commons Attribution (CC BY 4.0) license. Anyone may reproduce, distribute, translate and create derivative works of this article (for both commercial and non-commercial purposes), subject to full attribution to the original publication and authors. The full terms of this license may be seen at: http://creativecommons.org/licences/by/4.0/legalcode

Vol. 10, No. 11, 2020, Pg. 1006 - 1015

Full Terms \& Conditions of access and use can be found at http://hrmars.com/index.php/pages/detail/publication-ethics 


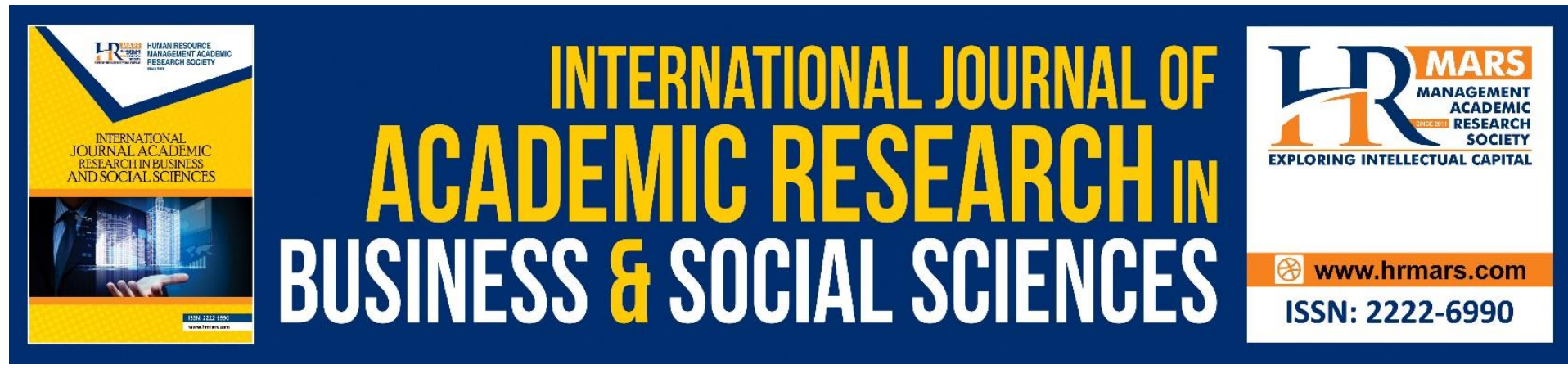

\title{
The Psychological Well-Being of 'Houseman' Medical Officers in Malaysia
}

\author{
Tambol Z., Bakar, A. Y. A., Mahmud, M. I., \& Karim, D. N. F. M. \\ Faculty of Education, Universiti Kebangsaan Malaysia, 43600 Bangi, Selangor, Malaysia \\ Email: yazid3338@ukm.edu.my
}

\begin{abstract}
'Housemanship' is one of the most challenging phases for a person who wants to become a doctor and wants to choose medicine as his or her career. This paper aims to discuss the psychological well-being issues that are often faced by 'houseman' medical officers throughout their undergoing housemanship. Literatures search was conducted based on previous studies related on well-being and psychological well-being issues faced by 'houseman' medical officers. This initial literature reviews' study confirmed that many 'houseman' doctors experienced considerable stress, anxiety, depression and burnout. The source of stress was multi-faceted, but workload wass the most significant stressor. Having good coping strategies help them to overcome their problem and might relief stress and could foster good psychological well-being during their training duration.
\end{abstract}

Keywords: 'Houseman', Medical Officer, Psychological Well-Being, Malaysia

Introduction

A 'houseman' medical officer is a trainee doctor who has just graduated from any medical schools and is in a period of observation and evaluation before he or she can be discharged to serve and be fully responsible for all decisions made against the patients. 'Housemanship' is a process for them to translate anything learned during medical school into practical form. This is the time for them to apply what they have learned to real world.

In simple words, 'housemanship' is a transitional phase of a medical graduate before being fully licensed and confirmed as a medical practitioner. Malaysian Medical Act 1971 defines 'Housemanship' as the period of training in resident medical practice for the purpose of being fully registered medical practitioner. This mandatory training is to produce healthcare professional and patient-oriented doctors for the betterment of our public health services (Tan et al., 2013).

In Malaysia, every 'houseman' medical officers will go through six postings every four months. These six posts are the Department of General Medicine, Department of General Surgery, Department of Orthopedics, Department of Pediatrics, Department of Obstetrics and Gynaecology, and also the Department of Emergency/Anaesthesiology/Psychiatry/ Family Medicine (Health Clinic) (Kementerian Kesihatan Malaysia, 1996). 
Early 'housemanship' is a crucial time in career development of 'houseman' medical officers. In the early few months of 'houseman' medical officers, they may have new role of responsibilities and expectations. In fact, early 'housemanships' are wrestling times with the role transition, from dependent to autonomous, from accountable to responsible, from learner to teacher, from supporter to leader (Ackerman et al., 2009). At this point, 'houseman' medical officers will find memorable scene that could provide them with insight into their developing professional identities.

However, during 24 months of 'housemanship', the junior medical officers will frequently encounter intense experiences that may affect their quality of life and well being. The purpose of this study was to explore the factors related to 'houseman' officers' psychological wellbeing during 'housemanships'.

\section{Psychological Well-Being}

According to World Hapiness Report 2015, Malaysia was ranked $61^{\text {st }}$ out of 158 countries audited for its' population happiness rate (Helliwell, Layard \& Sachs, 2015). These findings indirectly indicate that the level of psychological well-being of Malaysians is not at a positive level. The elements of psychological well-being are diverse, yet what is important is that they lead to happiness either internally or externally. Hence, many researchers see these aspects in varying conditions. This situation proves that sensitivity in psychological well-being by an individual depends on how they control themselves wisely. This is in line with the concept of psychological well-being stated by Bradburn, happiness and serenity is the result of psychological well-being and is the goal the highest that every human being wants to achieve. From the Islamic perspective, psychological well-being refers to the spiritual aspects that reflect the human heart, soul, mental and psychology (Hassan, 2000). Whilst, Ryan and Deci (2001), defines psychological well-being as an experience and optimal psychological functioning of an individual. It is not just an interpersonal relationship but more towards intense scientific. In line of that, The World Health Organisation (2003) referring psychological well-being as individuals who are healthy and mentally prosperous who are able to maintain harmonious relationships with others, participate in community activities and can thrive in society.

Psychological well-being is directly proportional to the quality of life of an individual. Quality of life (QOL) as an individual's perception of their position in life, in the context of culture and value system in which they live and their relationship to the responsibility, expectations, standard and concerns (World Health Organisation, 2010). WHO has outlined four key elements that affect quality of life. These elements are psychological, physical health, social relationships and environment.

Thus, psychological well-being can be concluded as a person's psychological state formed from life experiences his daily being subjectively assessed as well as the extent to which it is evaluate his ability to subjectively express himself. Ryff and Keyes (1995) claims that psychological well-being consists of six dimensions namely self-acceptance, positive relationships with others (positive relations), autonomy, environmental mastery, purpose in life and personal growth. For autonomy, the measurement revolves around the evaluation of strong personal standards, independent of others and ready for all the challenges in life. The second dimension, on the other hand, is the mastery of the environment like having more 
towards control good environment and make things affectively follows its' suitability. Dimensions for positive relationships with others refer to liking, empathy, and understand the relationship in a good element. Whilst, dimensions of self-development involving feelings who is constantly evolving and ready to find something latest in life. The dimension of goals in life refers to having fully defined life objectives. Finally is the dimension of self-acceptance which carries the meaning of positive behaviors and attitudes in life. Descriptions related to the elements of psychological well-being by Ryff are as follows in Table 1:

\begin{tabular}{ll}
\hline \multicolumn{1}{c}{ PWB Variable } & \multicolumn{1}{c}{ Definition } \\
\hline & $\begin{array}{l}\text { Feelings of competence and capacity to manage and } \\
\text { meet the responsibilities of everyday life / one's ability } \\
\text { to choose or create an environment which corresponds } \\
\text { to the psychological state of the self in context self } \\
\text { development }\end{array}$ \\
\hline
\end{tabular}

Purpose in Life and that past and present experiences are meaningful / clarity of life purpose is an important part of mental health features on someone

\begin{tabular}{cl}
\hline \multirow{2}{*}{ Autonomy } & $\begin{array}{l}\text { The extent to which one views oneself as self- } \\
\text { determining and independent, resisting pressure to } \\
\text { meet social expectations / ability to determine for } \\
\text { yourself the ability to regulate behavior and freedom }\end{array}$ \\
\hline $\begin{array}{c}\text { Positive Relations with } \\
\text { Others }\end{array}$ & $\begin{array}{l}\text { The sense that one has warm, satisfying, and trusting } \\
\text { relationships and are socially concerned/one's ability to } \\
\text { build relationships who are familiar with others }\end{array}$ \\
\hline Self-Acceptance & $\begin{array}{l}\text { The capacity for accepting and acknowledging one's } \\
\text { strengths and virtues as well as recognizing one's } \\
\text { weaknesses / positive assessment of one's condition }\end{array}$ \\
\hline Personal Growth & $\begin{array}{l}\text { Capacity for continued development, potential, and } \\
\text { openness to experience / Acquisition of personal } \\
\text { characteristics from previous experience and continues } \\
\text { to grow. }\end{array}$ \\
\hline
\end{tabular}

Table 1: Summary of PWB variables and their definitions Source: Ryff \& Keyes (1995)

\section{Psychological Well-Being of 'Houseman' Medical Officers in Malaysia}

Happiness at work is very important for individuals because if they happy in the workplace have a positive perception that makes individuals satisfied, productive, and low turnover make a total amount of quality manpower (Ningsih, 2013). In recent years, there has been an increasing interest research regarding psychological well-being issues among employees (Yunus \& Mahajar, 2011), students (Trpcevska, 2017; Rozubi, 2017; Alim et al., 2016; Omar, 2009; Nordin \& Talib, 2009), parents (Desa et al., 2015; Hassan, 2014; Hassan 2013), old citizens (Mudayat, 2014), patients (Bahari, 2016), and professionals (Cvejic et al., 2017; 
Mahani, Shahrir \& Melati, 2017; Nor, 2011; Ratanasiripong \& Wang, 2011; Agur \& TenıasBurillo, 2004).

Table 2, shows the total number of house officers who managed to get full registration from Malaysian Medical Association (MMA) and the number of house officers who could not complete the 'housemanship' within 24 months. From this data, shows that there is something happened or faced by 'houseman' officers during their 'housemanships'. In 2008, $77.4 \%$ of them successfully completed full registration after the completion of the training within 24 months compared to only 14.7\% in 2016. In addition, the number of 'houseman' officers who could not complete their training was only tremendously increased from 2008 to 2016. Was there a problem here?

\begin{tabular}{|c|c|c|c|c|c|c|c|c|c|c|}
\hline $\begin{array}{c}\text { Event/Yea } \\
r\end{array}$ & 2008 & 2009 & 2010 & 2011 & 2012 & $\begin{array}{c}201 \\
3\end{array}$ & 2014 & 2015 & 2016 & 2017 \\
\hline $\begin{array}{l}\text { Houseman } \\
\text { officer } \\
\text { obtain full } \\
\text { registration } \\
\text { within } 24 \\
\text { months }\end{array}$ & $\begin{array}{c}1853 \\
(77.4 \\
\%)\end{array}$ & $\begin{array}{c}2548 \\
(84.6 \\
\%)\end{array}$ & $\begin{array}{c}2519 \\
(81.2 \\
\%)\end{array}$ & $\begin{array}{c}2672 \\
(76 . \\
9 \%)\end{array}$ & $\begin{array}{c}2744 \\
(72 . \\
6 \%)\end{array}$ & $\begin{array}{c}268 \\
7 \\
(65 . \\
6 \%)\end{array}$ & $\begin{array}{c}2094 \\
(58.8 \\
\%)\end{array}$ & $\begin{array}{c}2096 \\
(48.6 \\
\%)\end{array}$ & $\begin{array}{c}1227 \\
(26.4 \\
\%)\end{array}$ & $\begin{array}{l}561 \\
(14 . \\
9 \%)\end{array}$ \\
\hline $\begin{array}{l}\text { Houseman } \\
\text { officer } \\
\text { cannot } \\
\text { finish } \\
\text { housemans } \\
\text { hip within } \\
24 \text { months }\end{array}$ & $\begin{array}{c}368 \\
(22.6 \\
\%)\end{array}$ & $\begin{array}{c}430 \\
(15.4 \\
\%)\end{array}$ & $\begin{array}{c}574 \\
(18.8 \\
\%)\end{array}$ & $\begin{array}{l}795 \\
(23 . \\
1 \%)\end{array}$ & $\begin{array}{c}1016 \\
(27 . \\
4 \%)\end{array}$ & $\begin{array}{c}141 \\
2 \\
(34 . \\
4 \%)\end{array}$ & $\begin{array}{c}1441 \\
(41.2 \\
\%)\end{array}$ & $\begin{array}{c}2219 \\
(51.4 \\
\%)\end{array}$ & $\begin{array}{c}3402 \\
(73.6 \\
\%)\end{array}$ & $\begin{array}{c}2872 \\
(85 . \\
1 \%)\end{array}$ \\
\hline
\end{tabular}

Table 2: The 10-years completion status of 'Houseman' medical officers in Malaysia Source: (Lim Chee Han 2019)

Previous research by Nogueira et al. (1997) have disscused outlined based on psysholgical and psychiatric morbidity among residents. In these study reported depression and sleep deprivation appear to be two of the most significant psychological problems that affect residents and are considered to be the main symptomatic reactions to this period. A number of researchers also have reported sleep deprivation among house officers is of growing concern. In developing countries, junior physicians are highly susceptible to develop sleep impairment due to long working hours, on-call duties and shift work schedule (Surani et al., 2015; Baldwin, Daugherty \& Yaghmour, 2011; Cramer et al., 2016; Deary \& Tait, 1987; Fargen, Larrew \& Turner, 2019; Wali et al., 2013; Weiss, Kryger \& Knauert, 2016).

The issue of 'houseman' medical officers has received considerable critical attention from many researchers. A considerable amount of literature has been published on burnout and stress among 'houseman' medical officers. Studies about stress and burnout among 'houseman' junior doctors were done locally and abroad (Samsudin, Isahak \& Rampal, 2018; Wu et al., 2018; O.Imo, 2017; Stawicki, 2017; Tallentire et al., 2017; Chin et al., 2016; Soares \& Chan, 2016; Crock \& Crock, 2015; Kim Lee \& Choi, 2015; Mata et al., 2015; Vivekanandan et al., 2016; Zuraida \& Zainal, 2015; Eley et al., 2013). Their studies shown that burnout may 
precede chronic stress and depression, in which case, burnout inventions could serve as protective treatment for chronic stress and depression in house officers. Thus, increases in stress will predict a decrease in job satisfaction.

In Malaysia, there have been researchers who study issues of psychological well-being among 'houseman' medical officers since the 1970's. Those issues include stress, anxiety, depression, and burnout. A list of studies in Malaysia can be found in Table 3.

\begin{tabular}{ll}
\hline \multicolumn{1}{c}{ Authors } & \multicolumn{1}{c}{ Issues } \\
\hline Ismail et al. 2020 & $\begin{array}{l}\text { Stress, anxiety, and depression; coping } \\
\text { strategies }\end{array}$ \\
\hline Sulaiman et al. 2018 & $\begin{array}{l}\text { Burnout, organizational justice, and role } \\
\text { ambiguity }\end{array}$ \\
\hline \multirow{3}{*}{ Lim Chee Han 2017 } & Extended housemanship \\
\cline { 2 - 2 } & Incompetence or poor work performance \\
\cline { 2 - 2 } Shahruddin et al. 2016 & Disciplinary; absent from work \\
\hline Vivekanandan et al. 2016 & Stress and anxiety \\
\hline Chin et al. 2016 & Perceived stress \\
\hline
\end{tabular}

Table 3: The studies about 'houseman' medical officers in Malaysia

The authors describe stress and burnout response syndrome among 'houseman' medical officers in training. The findings of the study indicate that housemanship, family relation and lack of courage severely affected house officers, however, may also suffer from major depression, suicidal ideation, and substance abuse. Possible contributing stresses include sleep deprivation, excessive work load, patient care responsibility, perpetually changing work conditions, and competition (Small, 1981). A primary concern of 'houseman' medical officers is they feel undervalued due to poor team working and relationships, bullying, workload, resources, and lack of positive feedback. And what makes 'houseman' medical officers feel no autonomy is lack of appropriate responsibility for clinical decision making, clinical complexit, overburdening and too much senior input, and reducing autonomy to make decision (Singh et al., 2019).

Recent evidence suggests that suggest the need for interventions to provide positive coping skills in handling the specific stressors. Finally, to improve psychological well-being among 'houseman' medical officers, six dimensions namely self-acceptance, positive relationships with others (positive relations), autonomy, environmental mastery, purpose in life and personal growth of psychological well-being should be taken seriously and given due attention by 'houseman' medical officers.

\section{Methodology}

This research will be conducted using the mixed method design, whereby both quantitative and qualitative approaches will be combined. It is going to be an explanatory mixed method research conducted in two sequential phases. In the first phase, the study will deploy a survey questionnaire which will gather data on psychological well-being among sampled 'houseman' 
medical officers. It is then followed by the second phase in which the in-depth interview wil be conducted using a semi-structured protocol in order to collect information to further explain vital data from the first phase.

The stratified random and purposive sampling procedures will be employed to sample research participants in both phases, while Statistical Package for Social Sciences (SPSS) version 23.0 and NViVo version 10 will be used as data analysis tools for both quantitative and qualitative phases.

\section{Conclusion}

The experiences of internship provide many potential triggers for personal growth. The balance between facilitators and barriers helps to determine whether personal growth is more or less likely to occur. Experience and responsibilities throughout housemanship should mature them and others should engage with them to identify improvements to improve their well-being and working lives. 'Houseman' medical officers should know their limitations and when and how to seek support. This can be sought from healthcare professionals other than doctors, where relevant.

\section{Acknowledgement}

The authors are thankful to Faculty of Education, Universiti Kebangsaan Malaysia for funding the publication of this article via research grant (Research Code: GG-2017-019).

\section{References}

Ackerman, A., Graham, M., Schmidt, H., Stern, D. T., \& Miller, S. Z. (2009). Critical events in the lives of interns. Journal of General Internal Medicine, 24(1), 27-32.

Agur, V. E., \& Tenıas-Burillo, J. M. (2004). Psychological well-being among hospital personnel: The role of family demands and psychosocial work environment. International Archives of Occupational and Environmental Health, 77, 401-408.

Aizat, S. S., Saseedaran, P., Salleh, A., Azmi, C. A. A., Izwan, M. N. H., Fuad, M. D., Nasir Al-Zurf, B. M. (2016). Prevalence and risk factors of stress, anxiety and depression among House Officers in Kota Kinabalu, Sabah. Education in Medicine Journal, 8(1), 31-40.

Baldwin, D. C., Daugherty, S. R., \& Yaghmour, N. A. (2011). Adding a depression measure to an assessment of sleepiness improves prediction of residency experience. Sleep, 34, 341-342.

Chin, R. W. A., Chua, Y. Y., Chu, M. N., Mahadi, N. F., Yusoff, M. S. B., Wong, M. S. \& Lee, Y. Y. (2016). Prevalence of burnout among Universiti Sains Malaysia medical students. Education in Medicine Journal, 8(3), 61-74.

Cramer, H., Kemper, K., Mo, X., \& Khayat, R. (2016). Are mindfulness and self-compassion associated with sleep and resilience in health professionals? Deutsche Zeitschrift fur Akupunktur, 59(2), 28-29.

Crock, C. T., \& Crock, E. A. (2015). Wellness, stress and junior doctors. Advances in Integrative Medicine, 2(2), 116-117.

Cvejic, E., Parker, G., Harvey, S. B., Steel, Z., Hadzi-Pavlovic, D., Macnamara, C. L., \& VollmerConna, U. (2017). The health and well-being of Australia's future medical doctors: Protocol for a 5-year observational cohort study of medical trainees. BMJ Open, 7(9).

Deary, I. J., \& Tait, R. (1987). Effects of sleep disruption on cognitive performance and mood in medical house officers. British Medical Journal (Clinical research ed.), 295(6612), 1513-1516. 
Desa, A., Yusooff, F., Zamani, Z. A., Kadir, N. B. A., \& Sani, M. N. M. (2015). Kemahiran keibubapaan, kefungsian keluarga dan kesejahteraan psikologi dalam kalangan ibubapa. Jurnal Psikologi Malaysia, 29(2), 32-42.

Eley, D. S., Cloninger, C. R., Walters, L., Laurence, C., Synnott, R., \& Wilkinson, D. (2013). The relationship between resilience and personality traits in doctors: Implications for enhancing well being. PeerJ, 1(1), e216.

Fargen, K. M., Larrew, T., \& Turner, R. D. (2019). Impact of a residency-integrated wellness program on resident mental health, sleepiness, and quality of life, Neurosurgery, 84(2), 341-346.

Government of Malaysia and United Nation Development. (1971). Medical Act 1971 (Amendment 2012) (March).

Hassan, A. (2014). Pengaruh faktor kesepaduan (kefungsian keluarga) dan kemahiran keibubapaan terhadap kesejahteraan psikologi dalam kalangan ibu bapa dan nak. Sains Humanika, 3(1), 99-105.

Hassan, A. (2013). Analisis gangguan kesejahteraan psikologi dan pengaruhnya terhadap kehibaan (grieving) dalam kalangan keluarga mangsa di Malaysia. Perspektif: Jurnal Sains Sosial dan Kemanusiaan, 6(2), 51-65.

Hassan, M. H. (2000). Pandangan Umum Islam Terhadap Kesihatan \& Perubatan. Singapura: PERDAUS.

Helliwell, J., Layard, R., \& Sachs, J. (2015). World Happiness Report 2015. New York City, NY: The Earth Institute, Columbia University: 1-171.

Ismail, M., Lee, K. Y., Tanjung, A. S., Jelani, I. A. A., Abdul Latiff, R., Abdul Razak, H., \& Ahmad Shauki, N. I. (2020). The prevalence of psychological distress and its association with coping strategies among medical interns in Malaysia: A national-level cross-sectional study. Asia-Pacific Psychiatry, (July), 1-8.

Kementerian Kesihatan Malaysia. (1996). Surat Pekeliling Ketua Pengarah Kesihatan Malaysia Bil 1/1996: Pelaksanaan Latihan Houseman.

Kim, K., Lee, S., \& Choi, Y. H. (2015). Relationship between occupational stress and depressive mood among interns and residents in a tertiary hospital, Seoul, Korea. Clinical and Experimental Emergency Medicine, 2(2), 117-122.

Lim, C. H. (2017). Housemanship programme in Malaysia: Availability of positions and quality of training, Penang Institute, (July).

Lim, C. H. (2019). Only 15pc of Malaysia's housemen Finish Training Within Two Years. CODE BLUE Health Is Human Right,. Retrieved from https://codeblue.galencentre.org/2019/09/09/only-15pc-of-malaysias-housemenfinish-training-within-two-years/

Mahani, I., Shahrir, J., \& Melati, S. (2017). The counselors psychological well-being. International Journal of Academic Research in Business and Social Sciences, 7(3), 733738.

Mata, D. A., Ramos, M. A., Bansal, N., Khan, R., Guille, C., Di Angelantonio, E., \& Sen, S. (2015). Prevalence of depression and depressive symptoms among resident physicians a systematic review and meta-analysis. JAMA - Journal of the American Medical Association, 314(22), 2373-2383.

Mudayat, N. A. (2014). Kesejahteraan psikologi dalam kalangan warga emas di rumah perlindungan orang tua di Selangor. Lifelong Learning International Conference 2014 (3LInC'14) Kesejahteraan, hIm.Vol. 2014, 978-983.

Ningsih, D. A. (2013). Subjective Well Being Ditinjau Dari Faktor Demografi (Status Perni- 
kahan, Jenis Kelamin, Pendapatan). Jurnal Online Psikologi, 1(2), 581-603.

Nogueira M. L., Stella, R. C., \& Nogueira, H. (1997). A pioneering experience in Brazil: the creation of a center for assistance and research for medical residents (NAPREME) at the Escola Paulista de Medicina, Federal University of São Paulo. Sao Paulo Medical Journal, 115(6), 1570-1574.

Nor, S. B. M. (2011). Pengaruh Kecerdasan Emosi dan Kesejahteraan sikologikal Terhadap Perkembangan diri Kaunselor Pelatih. Masters Thesis, Universiti Putra Malaysia.

Nordin, N. M., \& Talib, M. A. (2009). Kesunyian dan kesejahteraan psikologi di kalangan pelajar universiti di Malaysia. Jurnal Psikologi Malaysia, 23, 27-37.

O.Imo, U. (2017). Burnout and psychiatric morbidity among doctors in the UK: a systematic literature review of prevalence and associated factors. BJPsych Bulletin, 41, 197-204.

Omar, N. E. (2009). Kesejahteraan psikologi dalam kalangan pelajar IPTS. Jurnal Pendidikan Dan Latihan, 1(2), 1-11.

Ratanasiripong, P., \& Wang, C. C. D. C. (2011). Psychological well-being of Thai nursing students. Nurse Education Today, 31(4), 412-416.

Rozubi, N. C. (2017). Kesan Program Kesejahteraan Psikologi Menggunakan Kaedah Bermain Lepada Kanak-Kanak Sekolah Rendah. Tesis Doktor Falsafah, Universiti Malaya.

Ryan, R. M., \& Deci, E. L. (2001). On happiness and human potentials : A review of research on hedonic and eudaimonic well-being. Annual Review of Psychology, 52(1), 141-166.

Ryff, C. D., \& Keyes, C. L. M. (1995). The structure of psychological well-being revisited. Journal of Personality and Social Psychology, 69(4), 719-727.

Samsudin, E. Z., Isahak, M., \& Rampal, S. (2018). The prevalence, risk factors and outcomes of workplace bullying among junior doctors: A systematic review. European Journal of Work and Organizational Psychology, 27(6), 700-718.

Singh, R., Kirtley, J., Minhas, J. S., Lakhani, D., \& Carr, S. (2019). Exploring junior doctor morale in a UK hospital. Journal of the Royal College of Physicians of Edinburgh, 49(4), 312-316.

Small, G. W. (1981). House officer stress syndrome. Psychosomatics, 22(10), 860-864, 869.

Soares, D. S., \& Chan, L. (2016). Stress and wellbeing of junior doctors in Australia: A comparison with American doctors and population norms. BMC Medical Education, 16(1), 183.

Stawicki, S. (2017). Short timer's syndrome among medical trainees: Beyond burnout. International Journal of Academic Medicine, 3(3), 150.

Sulaiman, K. M., Saraih, U. N., \& Sakdan, M. F. (2018). Determinants of burnout among housemen : A conceptual paper. Proceedings of Symposium on Electrical, Mechatronics and Applied Science 2018 (SEMA'18), 2018(November), 161-162.

Surani, A., Zahid, S., Ali, S., Farhan, R., \& Surani, S. (2015). To assess sleep quality among Pakistani junior physicians (House Officers): A cross-sectional study. Ann Med Health Sci Res, Sep-Oct, 5(5), 329-333.

Tallentire, V. R., Smith, S. E., Facey, A. D., \& Rotstein, L. (2017). Exploring newly qualified doctors' workplace stressors: An interview study from Australia. BMJ Open, 7(8).

Tan, S. M. K., Jong, S. C., Chan, L. F., Jamaludin, N. A., Phang, C. K., Jamaluddin, N. S., \& Shah, S. A. (2013). Physician, heal thyself: The paradox of anxiety amongst house officers and work in a teaching hospital. Asia-Pacific Psychiatry, 5(SUPPL. 1), 74-81.

Trpcevska, L. (2017). Predictors of psychological well-being, academic self-efficacy and resilience in university students, and their impact on academic motivation. Tesis Doctor of Psychology, Victoria University.

Vivekanandan, G., Thirupathy, U., Affan, M., Zamri, A. A., Ariffin, K., Asraff, A., \& Sugnadan, S. 
(2016). Stress perceived by houseman in a hospital in northern Malaysia. Medical Journal of Malaysia, 71(1), 8-11.

Wali, S., Qutah, K., Abushanab, L., Basamh, R., Abushanab, J., \& Krayem, A. (2013). Effect of on-call-related sleep deprivation on physicians' mood and alertness. Annals of Thoracic Medicine, 8(1), 22.

Weiss, P., Kryger, M., \& Knauert, M. (2016). Impact of extended duty hours on medical trainees. Sleep Health, 2(4), 309-315.

World Health Organisation. (n.d.). WHOQOL: Measuring Quality of Life. https://www.who.int/healthinfo/survey/whoqol-qualityoflife/en/

World Health Organisation. (2003). The World Health Report : 2003 : Shaping the Future. Geneva: World Health Organization.

Wu, L., Farquhar, J., Vidyarthi, A. R., \& Ma, J., (2018). Understanding Singaporean medical students' stress and coping. Singapore Medical Journal, 59(4), 172-176.

Yunus, J. M., \& Mahajar, A. J. (2011). Stress and psychological well-being of government officers in Malaysia. The Journal of Human Resource and Adult Learning, 7(December), 40-50.

Zuraida, A., Psychiatry, N. Z.-M. J. of \& 2015, undefined. (n.d.). Exploring burnout among Malaysian junior doctors using the abbreviated Maslach Burnout Inventory. mjpsychiatry.org,. Retrieved from

http://mjpsychiatry.org/index.php/mjp/article/view/348

Zuraida, A., \& Zainal, N. (2015). Exploring burnout among Malaysian junior doctors using the Abbreviated Maslach Burnout Inventory. Malaysian Journal of Psychiatry, 24(1), 1-10. 